Balijagić, J., Arslanović, S., Mustajbašić, D. (2021): Medicinal plants fam. Asteraceae from Bjelasica Mountain used in folk and scientific medicine. Agriculture and Forestry, 67(1): 271-281

DOI: 10.17707/AgricultForest.67.1.22

\author{
Jasmina BALIJAGIĆ, \\ Sanida ARSLANOVIĆ ${ }^{2}$, Danira MUSTAJBAS̆IĆ ${ }^{3}$
}

\title{
MEDICINAL PLANTS FAM. ASTERACEAE FROM BJELASICA MOUNTAIN USED IN FOLK AND SCIENTIFIC MEDICINE
}

\section{SUMMARY}

The family Asteraceae (Compositae, sunflower family) is one of the most numerous families, with about 1,000 genera and more than 20,000 species distributed throughout the world. They are mostly herbaceous plants, but there are also shrubs, and less often trees and vines. This family also includes many medicinal species.

Geographical position, climatic conditions have enabled the rich biodiversity on the mountain Bjelasica in Montenegro, which is spread over an area of $620 \mathrm{~km}^{2}$. The geological base, which is mainly composed of silicate rocks, also affects the fact that not all recorded species are equally represented in Bjelasica. Some species are found in large and others in small quantities.

This research covers 15 species from the fam. Asteraceae that are used in medicine. Shoots are used from: Achillea milefolium L., Antennaria dioica (L) Gaertn, Bellis perennis L. Centaurea cyanus L. Cichorium intybus L. Matricaria chamomilla L., Tussilago farfara L., Petasites hybridus L., Taraxacum officinale Weber, Artemisia absinthium L., Solidago virguarea L. Underground organs are used from: Carlina acaulis L., Cichorium intybus L., Inula helenium L., Petasites hybridus L., Teraxacum officinale Weber and Telekia speciosa (Schreb.) Baumg. Arctium lappa $\mathrm{L}$.

Keywords: Bjelasica, medicinal plants, Asteraceae, Montenegro.

\section{INTRODUCTION}

The examined medicinal plants of the Asteraceae family are characterized by a whole range of vegetation forms. This includes annuals (Centaurea cyanus, Matricaria chamomilla,), biennials (Arctium lapa), herbaceous perennials (Achillea millefolium, Anternnaria dioica, Bellis perennis, Carlina acaulis,

\footnotetext{
${ }^{1}$ Jasmina Balijagić, (corresponding author: jasminab@ucg.ac.me), University of Montenegro, Biotechnical Faculty, Podgorica, MONTENEGRO.

${ }^{2}$ Sanida Arslanović, NGO Natura, Kolašin, MONTENEGRO

3 Danira Mustajbašić, Megatrend University, SERBIA

Notes: The authors declare that they have no conflicts of interest. Authorship Form signed online.

Recieved:03/02/2021

Accepted:28/03/2021
} 
Cichorium intybus, Inula helenium, Petasites hybridus, Taraxacum officinalis, Telekia speciosa, Tusilago farfara, Solidago virgurea) and perennial subshrub species (Artemisia absinthium).

The plants have underground organs in a shape of a crawling rhizome (Achillea millefolium, Anternnaria dioica), wooden rhizome (Artemisia absinthium), branched tuberous rhizome (Inula helenium, Solidago virgurea), short and knotted rhizome (Solidago virgurea), thick and spindle-shaped rhizome (Carlina acaulis) and spindle root (Arctium lapa, Centaurea cyanus, Cichorium intybus, Matricaria chamomilla).

Depending on the stem height, these medicinal plants can have no stem Carlina acaulis, short stem: Taraxacum officinalis $(2-10 \mathrm{~cm})$, Bellis perennis (about $15 \mathrm{~cm}$ ), Anternnaria dioica (about $20 \mathrm{~cm}$ ), Tusilago farfara (about $30 \mathrm{~cm}$.) i Petasites hybridus (about $40 \mathrm{~cm}$ ). Somewhat higher stems are found in Matricaria chamomilla (about $60 \mathrm{~cm}$ ), Centaurea cyanus (about $70 \mathrm{~cm}$ ), Achillea millefolium (about $80 \mathrm{~cm}$ ). Tall stems are found in Telekia speciose $(90-200 \mathrm{~cm})$, Artemisia absinthium $(120 \mathrm{~cm})$ Cichorium intybus, $(120 \mathrm{~cm})$ and Inula helenium $(150 \mathrm{~cm})$. Reproductive organs are round inflorescences bearing achene, oneseeded fruit.

The widespread distribution of the common dandelion, that is, Taraxacum officinale, along with its ability to tolerate a wide range of environmental conditions, makes this plant a good candidate as biological monitor of environmental metal contamination (Giacomino et al. 2016)

The study of the traditional uses of plants in the Ancona district, in the Marche region, Central Italy. The ethnobotanical data concern medicinal (122 species), the study increases present-day. knowledge of the traditional local uses of plants in the Marche region, medicinal and food uses, and of ethnobotanical aspects as a whole, , in terms of which will allow many of these uses to be preserved in the future (Lucchetti et al. 2019).

Abandonment or misuse (excessive grazing, fertilization) has led to the degradation of meadow vegetation and major changes in floristic composition and the extinction of many species. Such negative influences lead to qualitative and quantitative changes in meadow vegetation (Aćić, 2019)

In the work "Conspectus Florae Montenegrinnae" Rohlen (1942) published all the data on the distribution of medicinal plants in Bjelasica.

According to Pulević (1965), close to 300 plants are used in Montenegro as, to a greater or lesser extent, in the pharmaceutical industry and in folk medicine. Lakušić (1966) and Lakušić and Milojević (1972) gave their contribution to the study of the flora of Bjelasica. Medicinal plants of Bjelasica were the subject of graduate (Veljović; 2001) and Master's theses (Balijagić; 2009). Balijagic with associates (2009) published the Atlas of Medicinal Plants of the Bijelo Polje Region.

Organic production LAB in combination with the collection of wild plants and forest fruits can be a significant direction of development for many small family farms in hilly and mountainous areas (Stepanović and Radanović, 2011). 


\section{MATERIAL AND METHODS}

Mountain of Bjelasica (Figure 7) occupies an area in the central-continental part of the Montenegro, between $42^{\circ}$ and $43^{\circ}$ north latitude and $19^{\circ}$ and $20^{\circ}$ east longitude, having circular shape with $30 \mathrm{~km}$ in diameter. This area belongs municipalities of Andrijevica, Berane, Bijelo Polje, Mojkovac and Kolašin and it's borders are determined by the rivers Lim and Tara, and from the north, rivers Ljuboviđa and Lepenica. Along with these riverbeds, there are also roads that connect the mentioned municipalities and, in some way, determine the borders of Bjelasica in relation to other mountains.

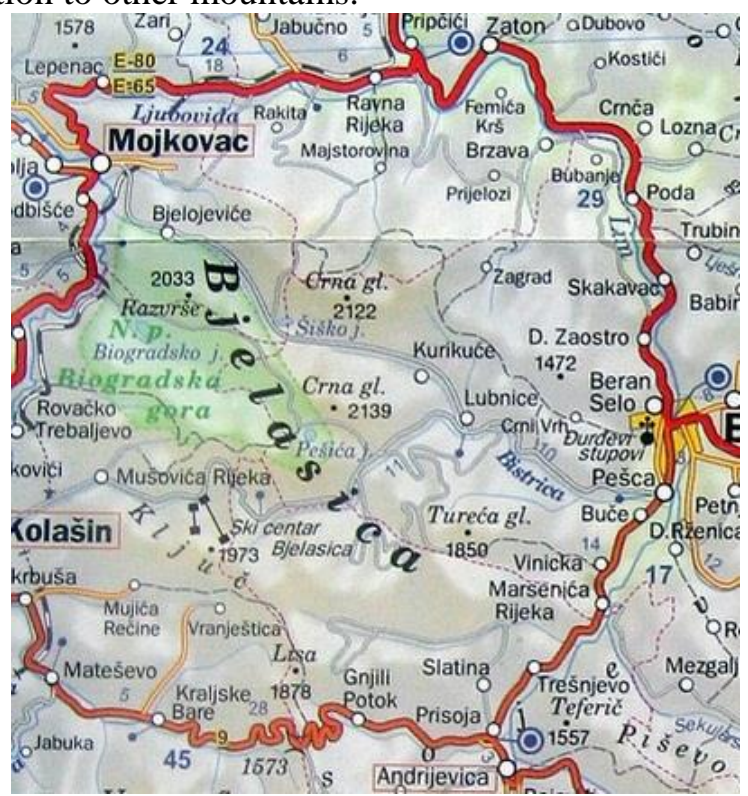

Figure 1. : Mountain Bjelasica

(Source: http://bjelasica.wifeo.com/srpski.php)

Bjelasica is a distinctly hilly and mountainous area. The dale of Tara and Lim up to $900 \mathrm{~m}$ altitude has the characteristics of a temperate continental climate, up to $1300 \mathrm{~m}$ it has the characteristics of humid continental climate and above that, alpine climate.

Thanks to the geological base, which is mainly composed of silicate rocks of volcanic origin, the relief of Bjelasica is divided by a dense network of watercourses, tributaries of the Tara and Lim and characterized by very easy passability and accessibility to the highest mountain peaks, great wealth of vegetation, abundance of running waters and extremely good potential for hiking.

Plants of family Asteraceae were determined on site or in the laboratory. For the determination of plants on the spot, we used illustrated bilinar (Horvatic et al., 1954) and Medicinal plants with a key for determination (Jančić, 2001). For determination in the laboratory, we used the Flora of SR Serbia Volume VII (Sarić et al., 1989), Systematic of Medicinal Plants (Živanović and Pavlović, 
1999), Guide to the World of Medicinal Plants (Tasić et al., 2009) and Atlas of Medicinal Plants of the Bijelo Polje Region (Balijagić et al., 2009).

The abbreviation BJ (2020) used in this paper represents the initial letters of the surname and name of Balijagić Jasmina. All pictures except the map are from private collection of Jasmina Balijagić.

\section{RESULTS AND DISCUSSION}

Acchillea milefolium L., Yarrow Verbena (Sarić et al., 1989) (Fig.1). It was found in the following localities: Jelovica, Biogradska gora, Mušovića rijeka, Paljevine, Tusta, Šiška, Gnjionik, Crni Vrh (Lakušić, 1966), Andrijevica (Pulević, 1965), Bjelasica (Lakušić and Milojević, 1972), Vinicka, Buče, Lubnice, Kršara (Lukić et al., 1992), Brzava, Buče, Majstorovina, Kordelj, Strmenica (Balijagić, 2009). Katun Rasova, Glavaca, Dolac (BJ et al., 2020). Cosmopolitan plant on Bjelasica. It grows on dry to moderately moist meadows, along roads, on rocky outcrops, forest glades, in katuns from the foothill to the alpine zone. The herbaceous above-ground part of the plant (Millefolii herba) is used, less often only the inflorescence (Millefolii flos) or only the leaf (Millefolii folium) in folk medicine and the pharmaceutical industry.

Antennaria diocia (L) Gaertn. Cudweed (Pulević V., 1965). It was found in the following localities: Zekova Glava, Troglav, Kosa Bjelasice (Lakušić R., 1966). It grows on meadows, pastures and rocky places in the alpine zone above $1600 \mathrm{~m}$ altitude. Inflorescences (Antennariae flos) and the above-ground part of the plant (Antennariae herba) are used in the form of tea in folk medicine.

Arctium lappa L. Burdock, Coltsfoots, Butterbur (Sarić M. Et al., 1989). It was found at the following localities: Bjelasica (Lakušić R. And Milojević B., 1972), Ravna Rijeka (Balijagić J., 2009), Lubnice (Balijagić J., et al. 2020). It grows on rudines, next to roads, unused pastures on the foothills. Moderately distributed on the mountain Bjelasica. The root (Bardanae radix) is used in the folk medicine.

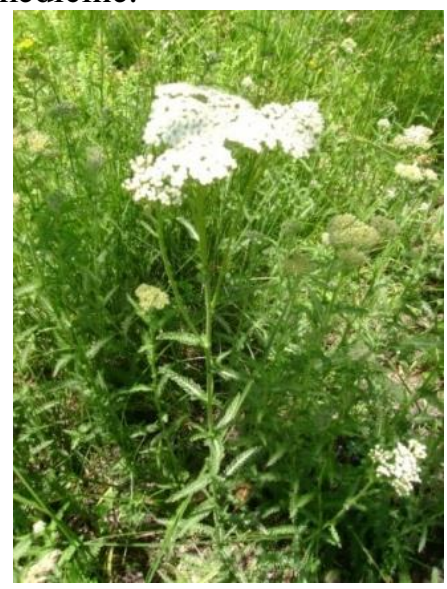

Figure 1. Acchillea milefolium L.

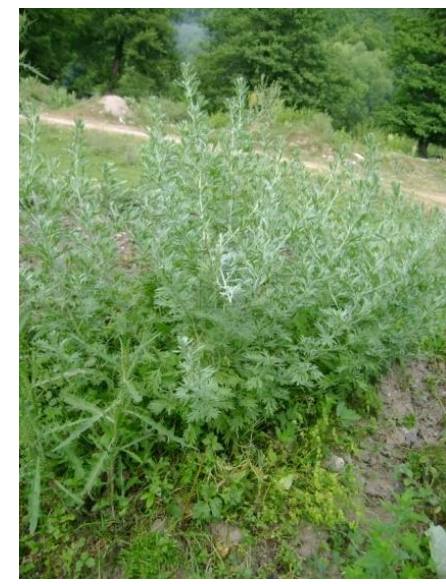

Figure 2. Artemisia absinthium L. 
Artemisia absinthium L. Wormwood (Pulević V., 1965) (Fig.2). It was found in the following localities: Vratilo - Kolašin (Rohlena J., 1942), Berane area, Andrijevica area, villages between Berane and Bijelo Polje (Lakušić R. And Milojević B., 1971), Buče (Lukić P. Et al. 1992), Brzava, Bubanje (Balijagić, 2009), Berane, Trebaljevo (BJ et al., 2020). It grows along roadsides on sandy, rocky limestone terrains, in sunny and dry places up to altitude of $1600 \mathrm{~m}$. It is less represented on the mountain Bjelasica due to the lack of limestone land. The herbaceous above-ground parts of the plant (Absinthii herba or Abshintii summitas) are used in folk medicine, and less and less often in scientific medicine.

Bellis perennis L. Daisy (Pulević V., 1965) (Fig.3). It was found at the following localities: Murgaš (Lakušić R., 1966), Bjelasica (Lakušić R. And Milojević B., 1972), Femića krš (Balijagić, 2009), Dolac, Crni Vrh (BJ et al., 2020). Commonly found on meadows and pastures up to altitude of $1700 \mathrm{~m}$. The inflorescence (Bellidis flos) is used, less often only the leaf (Bellidis folium) or the whole plant above-ground, without roots (Bellidis herba) as a folk remedy.

Carlina acaulis L. Silver thistle (Pulević V., 1965) (Fig.4). It was found in the following localities: Andrijevica (Rohlena J., 1942), National Park „Biogradska gora” (Veljović Đ., 2001), Kordelj, Rasova (BJ, 2020). Habitat: grows on sunny, mountain meadows. Quite widespread up to altitude of $2000 \mathrm{~m}$. It is an indicator of a healthy environment. The root (Carlinae radix) is used in folk medicine.

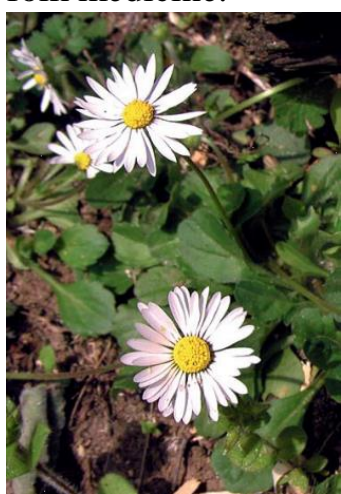

Figure 3. Bellis perennis $\mathrm{L}$.

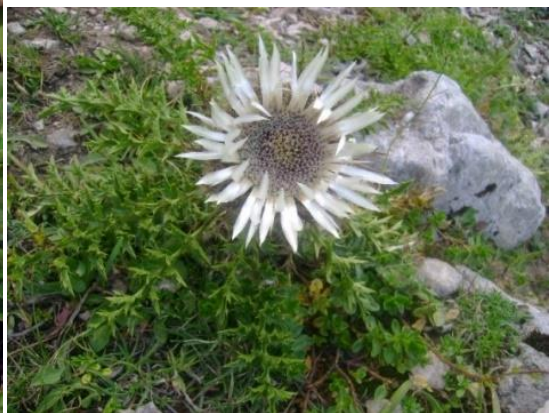

Figure 4. Carlina acaulis L.

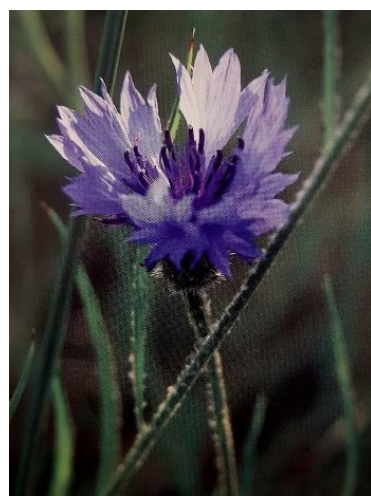

Figure 5. Centaurea cyanus $\mathrm{L}$.

Centaurea cyanus L. Cornflower (Pulević V., 1965). It was found at the following localities: Bjelasica (Lakušić and Milojević, 1972), Brzava (Balijagić, 2009), Crni Vrh (BJ, 2020). It grows on rocky, sunny terrains and in cultivated areas. Calciphilic species. It is poorly represented on the mountain Bjelasica. Lingual and adjacent tubular flowers without pappuses (Cyani flos sine calycibus) are used in folk medicine.

Cichorium intybus L. Chicory (Pulević V., 1965). It was found at the following localities: Bjelasica (Lakušić R. and Milojević B., 1972), National Park 
„Biogradska gora” (Veljović Đ., 2001), Brzava, Buče, Lubnice (Balijagić, 2009), Trbaljevo, Kurikuće, CrniVrh, Dolac (BJ et al., 2020). It grows in sunny places along roads, on meadows, abandoned places. Widespread species, up to altitude of $1200 \mathrm{~m}$. Medicinal uses include the root (Cichorii radix), less often the aboveground part of the plant (Cichorii herba) or only the flower (Cichorii flos). It's used more in folk than in scientific medicine.

Inula helenium L. Elecampane (Pulević V.,1965). It was found at the following localities: near Kolašin (Pulević, 1965), Bjelasica (Lakušić and Milojević, 1972), Biogradsko jezero (BJ et al., 2020). It grows on moist meadows, along forest edges, on the banks of streams and rivers. A rare species that is highly sought after. Rhizome with roots (Helenii rhizoma or Inulae, or Enulae radix) is used in folk medicine and as a medicinal raw material in the pharmaceutical industry.

Matricaria chamomilla L. Chamomile, (Sarić M. et al., 1989). It was found in the following localities: Kolašin (Rohlena J., 1942), Andrijevica, Kolašin (Pulević V., 1965), Bjelasica (Lakušić R. and Milojević B., 1972), National Park „Biogradska gora” (Veljović Đ., 2001; Vuković A., 2001), Majstorovina (Balijagić 2010), Lubnice, Glavaca, Trebaljevo (BJ et al., 2020). It grows on warm and dry terrains, mostly in the alpine zone. The chamomile flowers (Chamomillae flos) are used internally and externally, in folk medicine and as a medicinal raw material in the pharmaceutical industry.

Petasites hybridus L. Butterbur (Sarić M. et al., 1989). It was found in the following localities: upper basin of Tara and Lim (Blečić V., 1958), National Park „Biogradska gora” (Veljović D., 2001), Brzava, Ravna Rijeka (Balijagić, 2009), Lubnice, Kurikuće (BJ et al., 2020). It grows in moist meadows, along the banks of streams and rivers up to altitude of $1100 \mathrm{~m}$. The leaf (Petasitidis folium) is used in folk medicine.

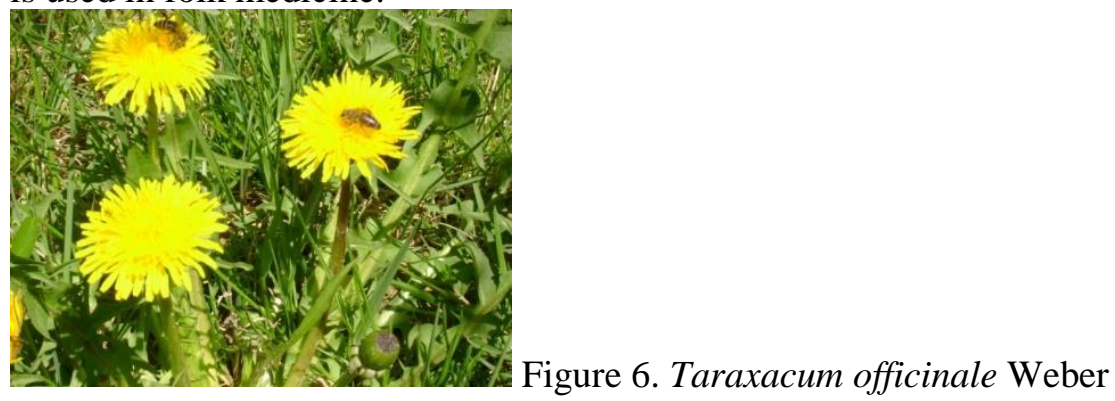

Taraxacum officinale Weber. Dandelion (Pulević V., 1965). It was found in the following localities: Jelovica, Šiška, Jarčeve strane, Troglav, Bjelilo, Otaševo lice (Lakušić R. 1966), Bjelasica (Lakušić R. and Milojević B., 1972), Buče (Lukić P. et al. 1992), National Park „Biogradska gora” (Veljović Đ., 2001), Majstorovina, Brzava, Prijelozi (Balijagić 2009), Lubnice, Kurikuće (BJ et al 2020). Widespread in mesophilic meadows in the subalpine and alpine zone. The root (Taraxaci radix) is used in folk medicine. 
Table 1. Officinal usage and specific parts used

\begin{tabular}{|c|c|c|c|c|c|c|}
\hline \multirow{2}{*}{ Species } & \multicolumn{4}{|c|}{ Plant parts used in medicine } & \multirow{2}{*}{ Officinality } & \multirow{2}{*}{ Action and usage } \\
\hline & folium & flos & herba & \begin{tabular}{|l} 
Radix/ \\
rhizoma
\end{tabular} & & \\
\hline \begin{tabular}{|l|} 
Achillea \\
milefolium $\mathrm{L}$.
\end{tabular} & $\begin{array}{l}\text { Milefolii } \\
\text { folium }\end{array}$ & Millefolii flos & $\begin{array}{l}\text { Millefolii } \\
\text { herba }\end{array}$ & & $\begin{array}{l}\text { Helv VII, } \\
\text { BHP19 90, } \\
\text { ÖAB 9, } \\
\text { Jug.II, } \\
\text { Komisija E. }\end{array}$ & $\begin{array}{l}\text { Antiphlogistic, } \\
\text { stomachic, } \\
\text { carminative, } \\
\text { cholagogue, } \\
\text { choleretic, } \\
\text { antispasmodic. } \\
\text { It is used in } \\
\text { disorders of the } \\
\text { digestive organs. } \\
\text { Externally in skin } \\
\text { inflammatory } \\
\text { processes and } \\
\text { mucous } \\
\text { membranes, for } \\
\text { rinsing wounds, } \\
\text { burns. }\end{array}$ \\
\hline $\begin{array}{l}\text { Antennaria } \\
\text { dioica }(\mathrm{L}) \\
\text { Gaertn. }\end{array}$ & & $\begin{array}{l}\text { Antennariae } \\
\text { flos }\end{array}$ & $\begin{array}{l}\text { Antennari } \\
\text { ae herba }\end{array}$ & & $\begin{array}{l}\text { Belg V, } \\
\text { PFX, } \\
\text { Komisija E. }\end{array}$ & $\begin{array}{l}\text { In the treatment of } \\
\text { diseases of the } \\
\text { bile and bile } \\
\text { ducts. In folk } \\
\text { medicine for } \\
\text { cough and chronic } \\
\text { bronchitis. }\end{array}$ \\
\hline $\begin{array}{l}\text { Arctium } \\
\text { lappa L. }\end{array}$ & & & & $\begin{array}{l}\text { Bardanae } \\
\text { radix }\end{array}$ & $\begin{array}{l}\text { PF X, } \\
\text { DAC 86, } \\
\text { BHP 83, }\end{array}$ & $\begin{array}{|lr|}\text { Diuretic } & \text { action } \\
\text { and } & \text { oxygen } \\
\text { properties. } & \text { Used } \\
\text { mainly } & \text { against } \\
\text { itchy skin. } & \\
\end{array}$ \\
\hline \begin{tabular}{|l|} 
Artemisia \\
absinthium $\mathrm{L}$
\end{tabular} & & & $\begin{array}{l}\text { Absinthii } \\
\text { herba - } \\
\text { Absinthii } \\
\text { summitas }\end{array}$ & & $\begin{array}{l}\text { DAB 10, } \\
\text { Helv VII, } \\
\text { ÖAB 90, } \\
\text { BHP 83, } \\
\text { Ph Eur. 6.0 }\end{array}$ & $\begin{array}{l}\text { Carminative, } \\
\text { cholagogue, } \\
\text { choleretic, } \\
\text { antispasmodic. In } \\
\text { the treatment of } \\
\text { bile and biliary } \\
\text { tract diseases. In } \\
\text { folk medicine for } \\
\text { stomach disorders } \\
\text { and mild } \\
\text { menstrual } \\
\text { problems. }\end{array}$ \\
\hline \begin{tabular}{|l} 
Bellis \\
perennis L
\end{tabular} & \begin{tabular}{|l} 
Bellidis \\
folium
\end{tabular} & Bellidis flos & $\begin{array}{l}\text { Bellidis } \\
\text { herba }\end{array}$ & & Hager. & $\begin{array}{l}\text { It has an } \\
\text { astringent anti- } \\
\text { inflationary } \\
\text { effect. It is used } \\
\text { internally for } \\
\text { coughs and } \\
\text { inflammation, to } \\
\text { relieve diarrhea, } \\
\text { liver and kidney } \\
\text { dysfunction. }\end{array}$ \\
\hline
\end{tabular}




\begin{tabular}{|c|c|c|c|c|c|c|}
\hline \begin{tabular}{|l} 
Carlina \\
acaulis $\mathrm{L}$
\end{tabular} & & & & \begin{tabular}{|l} 
Carlinae \\
radix
\end{tabular} & EB 6. & \begin{tabular}{|l} 
It has \\
antimicrobial, \\
antifungal, \\
diuretic, \\
diaphoretic and \\
antispasmodic \\
effects. In spasms \\
in the digestive \\
tract.
\end{tabular} \\
\hline $\begin{array}{l}\text { Centaurea } \\
\text { cyanus L. }\end{array}$ & & $\begin{array}{l}\text { Cyani flos sine } \\
\text { calycibus }\end{array}$ & & & $\begin{array}{l}\text { Komisija E, } \\
\text { Ph Eur. VI, } \\
\text { DAB 10, } \\
\text { Helv VII, } \\
\text { PF X, EB 6. } \\
\text { ÖAB 90, } \\
\text { BHP 83. } \\
\end{array}$ & $\begin{array}{l}\text { As a diuretic and } \\
\text { choleretic } \\
\text { remedy. }\end{array}$ \\
\hline \begin{tabular}{|l} 
Cichorium \\
intybus L.
\end{tabular} & & Cichorii flos & $\begin{array}{l}\text { Cichorii } \\
\text { herba }\end{array}$ & $\begin{array}{l}\text { Cichorii } \\
\text { radix }\end{array}$ & $\begin{array}{l}\text { PF VII, } \\
\text { Ital V, } \\
\text { Ph Eur. 6.0, } \\
\text { Komisija E. }\end{array}$ & $\begin{array}{l}\text { In the treatment of } \\
\text { diseases of the } \\
\text { liver, bile and bile } \\
\text { ducts. } \\
\text { Cholagogue } \\
\text { diuretic and as a } \\
\text { stomachic. }\end{array}$ \\
\hline $\begin{array}{l}\text { Inula } \\
\text { helenium } \mathrm{L}\end{array}$ & & & & $\begin{array}{l}\text { Helenii } \\
\text { rhizoma } \\
\text { Enulae radix }\end{array}$ & $\begin{array}{l}\text { PF X, EB 6, } \\
\text { BHP 90; } \\
\text { Ned.5, Pol.III }\end{array}$ & $\begin{array}{l}\text { Expectorant, } \\
\text { bactericidal, } \\
\text { holagogenic, } \\
\text { diuretic remedy. It } \\
\text { is used for dry } \\
\text { cough, bronchitis, } \\
\text { pneumonia. }\end{array}$ \\
\hline $\begin{array}{l}\text { Matricaria } \\
\text { chamomilla } \\
\text { L }\end{array}$ & & $\begin{array}{l}\text { Chamomillae } \\
\text { flos }\end{array}$ & & & Helv. VI. & $\begin{array}{l}\text { In disorders of the } \\
\text { digestive organs. } \\
\text { Externally in } \\
\text { inflammatory } \\
\text { processes on the } \\
\text { skin and mucous } \\
\text { membranes, for } \\
\text { rinsing wounds, } \\
\text { burns }\end{array}$ \\
\hline $\begin{array}{l}\text { Petasites } \\
\text { hybridus L. }\end{array}$ & $\begin{array}{l}\text { Petasitidis } \\
\text { folium }\end{array}$ & & & $\begin{array}{l}\text { Petasitidis } \\
\text { rhizoma }\end{array}$ & $\begin{array}{l}\text { HAB 1, } \\
\text { HPUS. 88, } \\
\text { Komisija E. }\end{array}$ & $\begin{array}{l}\text { Rhizome is used } \\
\text { in adjunctive } \\
\text { therapy for the } \\
\text { treatment of } \\
\text { spasmolytic pain } \\
\text { in the kidney and } \\
\text { also respiratory } \\
\text { diseases }\end{array}$ \\
\hline $\begin{array}{l}\text { Taraxacum } \\
\text { officinale } \\
\text { Weber }\end{array}$ & $\begin{array}{l}\text { Taraxaci } \\
\text { folium }\end{array}$ & & & $\begin{array}{l}\text { Taraxaci } \\
\text { radix }\end{array}$ & $\begin{array}{l}\text { Ph Eur 6.0, } \\
\text { BHP 90, } \\
\text { ÖAB 90, }\end{array}$ & $\begin{array}{l}\text { Bitter drug and } \\
\text { choleretic. It acts } \\
\text { as a diuretic, } \\
\text { laxative, } \\
\text { antirheumatic. }\end{array}$ \\
\hline \begin{tabular}{|l} 
Telekia \\
speciosa \\
(Schreb.)
\end{tabular} & & & & \begin{tabular}{|l} 
Telekiae \\
radix
\end{tabular} & $\begin{array}{l}\text { PF X, EB 6, } \\
\text { BHP 90; } \\
\text { Ned.5, Pol.III }\end{array}$ & \\
\hline
\end{tabular}




\begin{tabular}{|l|l|l|l|l|l|}
\hline $\begin{array}{l}\text { Tussilago } \\
\text { farfara } \mathrm{L} \\
\text { folium }\end{array}$ & $\begin{array}{l}\text { Farfarae } \\
\text { Farfarae flos }\end{array}$ & & $\begin{array}{l}\text { Helv VII, } \\
\text { EB 6, PF } \\
\text { VII, DAB } \\
10, \\
\text { BHP 9, }\end{array}$ & $\begin{array}{l}\text { For cough, asthma } \\
\text { and bronchitis. }\end{array}$ \\
\hline $\begin{array}{l}\text { Solidago } \\
\text { virguarea } \text { L. }\end{array}$ & & $\begin{array}{l}\text { virgaureae } \\
\text { herba }\end{array}$ & & $\begin{array}{l}\text { Ph.Eur.60, } \\
\text { BHP83, } \\
\text { PF X. }\end{array}$ & $\begin{array}{l}\text { In the treatment of } \\
\text { urological } \\
\text { diseases, prostate } \\
\text { hypertrophy, gout. } \\
\text { Externally - for } \\
\text { various skin } \\
\text { inflammations } \\
\text { and eczema. }\end{array}$ \\
\hline
\end{tabular}

Telekia speciosa (Schreb.) Baumg. Yellow Ox-eye (Sarić M. et al., 1989). It was found in the following localities: National Park „Biogradska gora” (Veljović Đ., 2001), Majstorovina, Jelovica (Balijagić, 2009), Kurikuće (BJ et al., 2020). Moderately distributed species, grows in beech and fir forests, along the banks of clear mountain streams and springs, up to altitude of $1600 \mathrm{~m}$. In folk medicine, roots are used (Telekiae radix).

Tussilago farfara L. Coltsfoot (Pulević V., 1965). It was found in the following localities: the valley of the river Bistrica and its tributaries, the valley of the Mušović river, the valley of Lim and Tara and their tributaries (Lakušić R. and Milojević B., 1972), Lubnica (Lukić P. et al., 1992), National Park „Biogradska gora” (Veljović Đ., 2001; Vuković A., 2001), Kordelj, Majstorovina, Brzava, Strmenica, Bubanje (Balijagić, 2009), Buče, Crni Vrh (BJ et al., 2020). It belongs to the first spring species. It grows in bare, moist, rocky, open and sunny habitats. It spreads up to altitude of $1500 \mathrm{~m}$. Moderately distributed. The leaf (Farfarae folium) and the flower (Farfarae flos) are used more in the folk than in the scientific medicine.

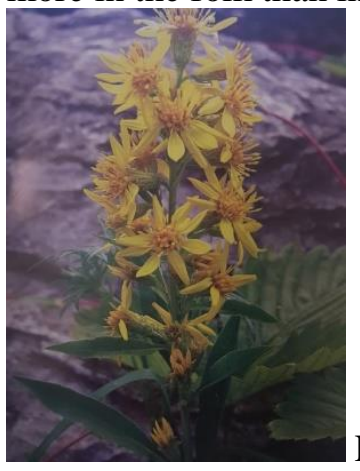

Figure 7. Solidago virguarea $\mathrm{L}$.

Solidago virguarea L. woundwort (Sarić M. et al. 1989). It is widespread on Bjelasica. It was found at the following sites: Bardov do, Rasova (Balijagić et al, 2009). It occurs mainly in forests and on different substrates, in open places in the highlands. It is represented on Bjelasica in large quantities. It is used (Solidaginis virgaureae herba) in scientific and folk medicine. 
Orientation quantities of Achillea milefolium L. are found in Bjelasica in large quantities (Lakušić and Milojević et al., 1992; Balijagić, 2009). The situation on the ground indicates that its representation has not changed even during our survey in 2020. According to Lakušić and Milojević (1972), Lukić et al., (1992), Balijagić (2009) and based on our research (2020) Taraxacum officinale, Weberi is also represented in large quantities. Based on the previous and our research from 2009 to 2020, Solidago virguarea L. is represented in large quantities.

The most common species in Bjelasica in 2020 is Bellis perennis L. as well as the species Cichorium intybus L. To a lesser extent (Lakušić and Milojević, 1972; Lukić et al., 1992; Balijagić (2009), the species Artemisia abshintium L. is represented and during our visit (2020) we found and recorded it on limestone soils. The calcified species Centaurea cyanaus $L$. is also poorly represented. Matricaria chamomillia L. and Telekia speciosa (Schreb.) Baumg are moderately represented on Bjelasica, while Inula helenium $L$. is a rare species that is in great demand.

\section{CONCLUSIONS}

Not all recorded species are equally represented in Bjelasica. Some species are found in large and some in small quantities.

The flower of seven species is used in folk and scientific medicine (Achillea milefolium L., Antennaria dioica (L) Gaertn, Bellis perennis L. Centaurea cyanus L. Cichorium intybus L. Matricaria chamomilla L., Tussilago farfara L.).

The leaf is used from five species (Achillea milefolium L. Bellis perennis L., Petasites hybridus L., Taraxacum officinale Weber, Tussilago farfara L.)

The aboveground part (herba) is used by five species (Achillea milefolium L. Antennaria dioica (L) Gaertn., Artemisia absinthium L. Bellis perennis L. Cichorium intybus L.)

Underground organs are used by seven species (Carlina acaulis L., Cichorium intybus L., Inula helenium L., Petasites hybridus L., Taraxacum officinale Weber, Telekia speciosa (Schreb.) Baumg.

Above-ground and underground parts are used by one species (Cichorium intybus L.)

Based on our research in 2020 and research from previous years, there have been no significant changes in the disturbance of the number of natural populations of the studied species.

This research was supported by the government of Montenegro and European Union (SOPPEES) 2015-2017.

\section{REFERENCES}

Aćić S. (2019): Floristic analysis of the grassland vegetation of the Molinio-Arrhenatheretea and Festuco-Brometea classes in Serbia. Acta Horticultura 28(1):77- 86 
Balijagić J. (2009): Ljekovite biljke planine Bjelasice - korišćenje i zaštita. Univerzitet Crne Gore, Prirodno-matematički fakultet, Podgorica

Balijagić J., Jovančević M., Vreva M. (2009): Atlas ljekovitih biljaka bjelopoljskog kraja. Merkator Internacional d.o.o, Bijelo Polje

Balijagić J., Markišić H., Jovančević M., Praščević M., Vincek D., Menković N. (2012): Contribution to the research of medicinal and other plants in the mountainous region of Čakor, Montenegro. Agriculture \&,Foresty Vol.57. (11)Issue 3:67-92

Blečić V.(1958): O nekim karakteristikama flore i vegetacije Crne Gore. Zaš. Prir. (Beograd) 13:1-6.

Giacomino A., Malandrino M., Colombo L. M., Miaglia S., Maimone P., Blancato S., Conca E. and Abollino O. (2016): Metal Content in Dandelion (Taraxacum officinale) Leaves: Influence of Vehicular Traffic and Safety upon Consumption as Food. Journal of C Chemistry / Volume 2016 |Article ID 9842987 | https://doi.org/10.1155/2016/9842987

Horvatič S. (1954): Ilustrirani bilinear. Školska knjiga, Zagreb

Lucchetti L., Zitti S., Fabio T. (2019): Ethnobotanical uses in the Ancona district (Marche region, Central Italy). Journal of Ethnobiology and Ethnomedicine. https://doi.org/10.1186/s13002-019-0288-1

Jančić R. (1990). Lekovite biljke sa ključem za određivanje. "Naučna knjiga", Beograd.

Josifović M., Blečić V., Vukićević E., Gajić M., Diklić N., Janković M. M., Stjepanović L., Tatić B. ( 1975): Flora SR Srbije, VII tom. Srpska Akademija nauka i umjetnosti, Beograd

Lakušić R.(1966): Vegetacija livada i pašnjaka na planini Bjelasici. ( Die Vegetation der Wiesen und Wieden des Bjelasice gerbiges ). God. Biol. Instit.. (Sarajevo) 19: 25-186.

Lakušić R. i Milojević B. (1972): Lekovito bilje na planinama Prokletija, Komova i Bjelasice. Tokovi (Ivangrad): 91-110, 1972.

Pulević V. (1965): Prilog poznavanju ljekovitog bilja u flori Crne Gore, njegovo iskorišćavanje i zaštita. Poljoprivreda i Sumarstvo (Titograd)11(3.4): 1748.

Rohlena J.(1942): Conspectus Florae Montenegrine, Praha.

Sarić M.: (1989): Ljekovite biljke SR Srbije. SANU, Beograd

Tasić S. Šavikin Katarina et Menković N. (2009): Vodić kroz svet ljekovitog bilja. Alexksandrija. Beograd 2009.

Veljović Đ., (2001): Lekovite biljke Nacionalnog parka „Biogradska gora“. Farmaceutski fakultet Beograd.

Živanović P. et Pavlović S. (1999): Sistematika lekovitih biljaka. JP Službeni list SRJ, Beograd. 